SPORT - Nauka i Praksa, Vol. 11, №1, 2021, str. 1-8.

Originalni naučni rad

\title{
RELACIJE BRZINE I SPECIFIČNIH MOTORIČKIH SPOSOBNOSTI PRIPADNIKA SPECIJALNIH JEDINICA ${ }^{1}$
}

\author{
UDK: 796.012.1-057.36(497.11) \\ https://doi.org/10.18485/snip.2021.11.1.1 \\ Mihajlo Golubović \\ Fakultet sporta i fizičkog vaspitanja, Univerzitet u Nišu, Srbija \\ Saša Veličković \\ Fakultet sporta i fizičkog vaspitanja, Univerzitet u Nišu, Srbija \\ Anđela Đošić \\ Fakultet sporta i fizičkog vaspitanja, Univerzitet u Nišu, Srbija \\ Saša Pantelić ${ }^{3}$ \\ Fakultet sporta i fizičkog vaspitanja, Univerzitet u Nišu, Srbija
}

\begin{abstract}
Apstrakt: Operativne sposobnosti pripadnika vojske definisane su faktorima morfologije, funkcije, nivoa motoričkih sposobnosti, zdravlja i dr. U specijalnim brigadama, za uspešnu realizaciju dodeljenih zadataka potreban je visok nivo motoričkih sposobnosti. Najvažnije motoričke sposobnosti pripadnika specijalnih brigada su izdržljivost, snaga, koordinacija, agilnost i brzina, kao i ravnoteža, preciznost i fleksibilnost. Ovi parametri međusobno moraju biti povezani kako bi se očekivala maksimalna uspešnost. Cilj istraživanja bio je da se utvrdi da li postoji povezanost brzine sa specifičnim motoričkim sposobnostima pripadnika specijalne brigade Vojske Republike Srbije. Uzorak su činila 74 ispitanika, pripadnici 63. padobranske brigade iz Niša. Za utvrđivanje brzine primenjeni su testovi: sprint na $10 \mathrm{~m}, 20 \mathrm{~m}$ i $30 \mathrm{~m}$. Specifične motoričke sposobnosti procenjivane su testovima: sklekovi na tlu za 2 minuta, dizanje trupa sa tla za 2 minuta, trčanje na $3200 \mathrm{~m}$, penjanje uz konopac $7 \mathrm{~m}$. Za utvrđivanje povezanosti brzine i parametara specifičnih motoričkih sposobnosti primenjena je kanonička korelaciona analiza. Obrada podataka utvrđena je pomoću statističkog paketa Statistica 8.0. Nivo značajnosti bio je .05. Rezultati su pokazali da su prostori brzine i specifičnih motoričkih sposobnosti međusobno povezani sa jednim parom statistički značajnih kanoničkih faktora na nivou značajnosti od .01 ( $p=.000)$. Izolovani par kanoničkih faktora objašnjen je sa $43 \%$ zajedničkog varijabiliteta.
\end{abstract}

Ključne reči: motoričke sposobnosti, specijalna brigada, brzina, relacije

\section{UVOD}

Studije pokazuju da pored funkcionalnih i antropometrijskih karakteristika, za postizanje uspeha u pojedinim sportovima veliki značaj ima i nivo određenih motoričkih sposobnosti bilo da se radi o odraslim osobama (Kasum, 2001; Karalejić i Jakovljević, 2008; Popović, 2010) ili o dečijem uzrastu (Bubnjević i sar., 2020). Takođe, uspešnost vršenja pojedinih fizičkih aktivnosti direktno određuje i nivo pojedinih motoričkih sposobnosti pojedinca

1 Rad primljen: 1.3.2021, korigovan: 23.3.2021, prihvaćen za objavljivanje: 23.3.2021.

Mihajlo Golubović je doktorand na Fakultetu sporta i fizičkog vaspitanja, Univerziteta u Nišu.

3凶panta@fsfv.ni.ac.rs 
(Nedeljković, 2007). Njihov udeo zavisi od velikog broja faktora, ali i od prirode i složenosti kretne strukture određene sportske grane ili discipline. Primer veoma izražene uloge pojedinih motoričkih sposobnosti u postizanju vrhunskih rezultata ogleda se npr. u realizaciji atletskih kretnih struktura, poput trkačkih, skakačkih ili bacačkih disciplina, gde se ostvaruju određene relacije koje se manifestuju kroz sportski rezultat (Pavlović i Radinović, 2010). Utvrđivanje nivoa motoričkih sposobnosti i antropoloških karakteristika i njihov uticaj na pojedine pokazatelje fizičkih sposobnosti aktuelan je problem ne samo u sportskoj praksi, već i u vojsci, gde se traži visok nivo fizičkih sposobnosti. Visok nivo fizičke sposobnosti u velikoj meri utiče na uspešnost u obavljanju mnogih zadataka (Hauschild et al., 2017), a samim tim i na povećanje borbene gotovosti jedinice.

Nivo operativnih sposobnosti pripadnika vojske definisan je nizom faktora koji se odnose na fiziološke i morfološke karakteristike, funkcionalne sposobnosti, nivo motorike, zdravlja i dr. (Marić, 2010; Šimenko et al., 2004). U vojsci, a naročito u specijalnim jedinicama, za uspešnu realizaciju dodeljenih zadataka potreban je visok nivo motoričkih sposobnosti. Pripadnici specijalnih brigada obuku i zadatke često izvode u otežanim meteorološkim uslovima i pod opterećenjem (zaštitna maska, borbena oprema, zaštitna odeća itd.), gde do izražaja dolazi ispoljavanje velikog broja motoričkih sposobnosti. Glavni faktori motorike koji su odgovorni za uspešno izvršavanje borbenih zadataka pripadnika specijalnih brigada su kardiorespiratorna izdržljivost i snaga (Družeta, 2008; Mattila et al., 2007; Mala et al., 2015). Pojedini autori tvrde da se uglavnom mišićna snaga i sila smatraju najvažnijim fizičkim atributima za izvođenje vojnih zadataka, dok se aerobnim sposobnostima pripisuje manji značaj (Pierce et al., 2017). Snaga nogu naročito ima veliki značaj kod izvršavanja dugotrajnih marševa pri odlasku i povratku sa vežbališta ili strelišta, prelasku određenih prepreka i dr. (Mattila et al., 2007; Družeta, 2008; Mala et al., 2015). Značaj eksplozivne snage može se uočiti kod savladavanja različitih poligona za obuku, brzih ukrcavanja i iskrcavanja iz borbenih vozila, upada u objekte i dr. (Pihlainen et al., 2018). Osim snage, aerobna izdržljivost je bitan faktor za realizaciju obuke i borbenih zadataka. Pripadnici specijalnih brigada u okviru redovne obuke realizuju marševe pod opterećenjem, $u$ otežanim meteorološkim uslovima, pri niskim i visokim temperaturama, gde ukupna dužina marša iznosi i do $50 \mathrm{~km}$, a opterećenje, odnosno težina borbene opreme, od $20 \mathrm{~kg}$ do $40 \mathrm{~kg}$.

Od drugih faktora koji utiču na povećanje borbene gotovosti jedinice i nivo operativnih sposobnosti izdvajaju se koordinacija, naročito koordinacija celog tela, brzina izvođenja složenih motoričkih zadataka, agilnost i brzina (Družeta, 2008). Takođe, ravnoteža, preciznost i fleksibilnost spadaju u motoričke sposobnosti koje su bitne u vojsci, a naročito u specijalnim jedinicama (Družeta, 2008).

Da bi se utvrdilo stanje motoričkih sposobnosti profesionalnih vojnih lica, a radi jednoobraznog izvođenja provere i ocenjivanja primenjuje se baterija testova preporučena za ovu populacionu grupu (Uputstvo za fizičku obuku Vojske Srbije, 2011).

Rezultati istraživanja koja su se bavila relacijama motoričkih sposobnosti kod pripadnika vojske uglavnom su se bazirala na utvrđivanju relacija telesne kompozicije i ostalih motoričkih sposobnosti (Glavač, 2015; Heinrich et al., 2008; Mullie et al., 2008; Crawford et al., 2011). Na osnovu rezultata dosadašnjih istraživanja (Grier et al., 2015; Nogueira et al., 2016) utvrđeno je da su BMI i procenat telesnih masti u jakoj negativnoj korelaciji sa aerobnim kapacitetom i rezultatima na vojnim testovima sposobnosti. Pojedine studije utvrđivale su uticaj motoričkih sposobnosti na realizaciju brzine kod pripadnika vojske (Maleš i sar., 2004). Autori zaključuju da veliki broj motoričkih spsobnosti učestvuje u uspešnosti trčanja, i da je integracija motoričkih sposobnosti sveprisutna.

Cilj rada bio je da se utvrdi da li postoji povezanost brzine sa specifičnim motoričkim sposobnostima kod pripadnika specijalnih jedinica Vojske Republike Srbije.

\section{METODE}

\section{Uzorak ispitanika}

Populacija koja je sačinjavala uzorak ispitanika bila je sastavljena od pripadnika 63. padobranske brigade u Nišu. Ukupan uzorak obuhvatio je 74 ispitanika muškog pola, prosečne starosti 33,3 $\pm 5,7$ godina. Prosečna telesna visina uzorka iznosila je $178,65 \pm 6,64 \mathrm{~cm}$, telesna masa $84,08 \pm 9,59 \mathrm{~kg}$, dok je BMI $26,33 \pm 2,41 \mathrm{~kg} / \mathrm{m} 2$. Ispitanici obuhvaćeni ovim uzorkom spadaju u grupu fizički aktivne populacije. U sklopu fizičke obuke svakodnevno izvode časove fizičkog vežbanja u trajanju od $90 \mathrm{~min}$. U trenutku sprovođenja istraživanja svi ispitanici imali su uredan zdravstveni status. 


\section{Uzorak mernih instrumenata}

U skladu sa ciljem istraživanja primenjeni su testovi za procenu brzine i testovi za procenu specifičnih motoričkih sposobnosti.

Merni instrumenti za procenu brzine

Za procenu brzine trčanja primenjeni su sledeći testovi (Veličković et al., 2013; Jukić i sar., 2008):

- sprint na $10 \mathrm{~m}$,

- sprint na $20 \mathrm{~m}$ i

- sprint na $30 \mathrm{~m}$.

Merni instrumenti za procenu specifičnih motoričkih sposobnosti

Za procenu specifičnih motoričkih sposobnosti primenjeni su testovi koji se primenjuju prilikom provere motoričkih sposobnosti u Vojsci Srbije (Uputstvo za fizičku obuku Vojske Srbije, 2011):

- sklekovi na tlu za 2 minuta,

- dizanje trupa sa tla za 2 minuta,

- trčanje na 3200 metara i

- penjanje uz konopac 7 metara.

\section{Opis mernog postupka}

Za potrebe istraživanja bili su stvoreni neophodni optimalni uslovi prilikom merenja.

Merenje antropometrijskih karakteristika bilo je prema metodi Centers for Disease Control and Prevention (2017), a BMI je izračunat na osnovu obrasca koji je predložila Svetska zdravstvena organizacija (WHO, 1997).

Za procenu brzine korišćen je WITTY SEM sistem za elektronsko merenje vremena sa foto ćelijama. Ispitanik je iz visokog starta imao zadatak da pređe što brže razdaljinu od $30 \mathrm{~m}$, a foto-ćelije postavljene na startnoj liniji, na $10 \mathrm{~m}, 20 \mathrm{~m}$ i na $30 \mathrm{~m}$ beležile su vreme. Primenjeni testovi imaju zadovoljavajuće metrijske karakteristike, i sa istom opremom korišćeni su i u drugim istraživanjima (Duthie et al., 2006; Jukić i sar., 2008).

Specifične motoričke sposobnosti testirane su na osnovu Uputstva za fizičku obuku u Vojsci Srbije i Standardima za ocenjivanje fizičkih sposobnosti vojnih lica u Vojsci Srbije (Uputstvo za fizičku obuku Vojske Srbije, 2011). Primenom baterije testova za proveru fizičkih sposobnosti procenjivala se: repetitivna izdržljivost u snazi ruku, ramenog pojasa, grudnih mišića i trupa, zatim aerobna izdržljivost i izdržljivost mišića nogu, kao i opšta fizička sposobnost. Primenjeni testovi imaju zadovoljavajuće metrijske karakteristike (Jukić i sar., 2008; Dhahbi et al., 2015).

\section{Sklekovi na tlu za 2 minuta}

Iz početnog položaja u skleku ispitanik kreće sa izvođenjem sklekova. Kao ispravan sklek broji se pokušaj kada ispitanik spusti celo telo, dok mu nadlaktice ne budu paralelne sa tlom, a zatim se vrati u početni položaj. Pri svakom ponavljanju telo mora ostati u pravoj liniji. Nakon isteka dva minuta test se prekida, rezultat je broj ispravnih ponavljanja tokom dva minuta. Ovaj test ima zadovoljavajuće metrijske karakteristike, što je svojim ispitivanjem potvrdila grupa autora (Jukić i sar., 2008).

\section{Dizanje trupa sa tla za 2 minuta}

Iz početnog stava ležećeg na leđima sa kolenima savijenim pod uglom od $90^{\circ}$ i stopalima rastavljenim u širini kukova, koja su pridržavana od strane drugog ispitanika, sa rukama prekrštenim i priljubljenim na grudi, ispitanik izvodi trbušnjake. Tokom izvođenja testa, ruke su sve vreme na grudima. Nakon isteka dva minuta kao rezultat, upisuje se broj ispravnih ponavljanja tokom dva minuta.

Trčanje na 3200 metara

Ispitanici započinju trčanje, a istovremeno počinje i merenje vremena. Nakon istrčanih 3200 metara, merilac kao rezultat testa upisuje vreme za koje je ispitanik pretrčao naznačenu deonicu. Vreme se upisivalo sa tačnošću od jedne sekunde (minuta, sekundi).

Penjanje uz konopac od 7 metara

Iz početnog stava u kome je ispitanik stajao pored konopca i jednom rukom se držao za konopac, na komandu merioca započinje penjanje uz konopac. Tehniku penjanja birao je sam ispitanik. Test se završavao kada je ispitanik 
rukom dodirnuo marker koji je označavao visinu od $7 \mathrm{~m}$, a vreme je upisivano sa tačnošću od $0.10 \mathrm{~s}$ (sekunda, deseti deo sekunde).

\section{Statistička obrada podataka}

Za obradu i analizu sirovih podataka korišćen je statistički paket za obradu podataka Statistica 8.0 for Windows (StatSoft, Inc., Tulsa, OK).

Izračunati su osnovni parametri deskriptivne statistike i distribucije (aritmetička sredina, standardna devijacija, minimalna i maksimalna vrednost, raspon, koeficijent zakrivljenosti - skjunis, koeficijent zaobljenosti - kurtosis). Za utvrđivanje povezanosti između brzine i parametara specifičnih motoričkih sposobnosti koristila se kanonička korelaciona analiza. Izračunati su koeficijent kanoničke korelacije, procenat zajedničke varijanse, značajnost veza istraživanog prostora, stepen slobode i statistička značajnost kanoničke korelacione analize. Nivo značajnosti bio je .05 .

\section{REZULTATI}

U Tabeli 1 prikazani su parametri deskriptivne statistike i distribucije primenjenih varijabli za procenu brzine i specifičnih motoričkih sposobnosti.

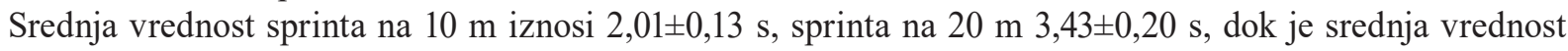
sprinta na 30 m iznosi 4,78 $\pm 0,28 \mathrm{~s}$. Vrednosti skjunisa (Skew) ukazuju da nema izražene asimetrije. Rezultati imaju blagu pozitivnu asimetričnost (epikurtičnost), što ukazuje da postoji više dobrih rezultata, ali se može konstatovati da se nalaze u granicama dozvoljenih odstupanja. Najniža vrednost koeficijenta zakrivljenosti (Skew) iznosi ,42 za sprint na $10 \mathrm{~m}$, dok je najviša 1,12 za sprint na $30 \mathrm{~m}$. Vrednosti kurtosisa (Kurt) ukazuju da varijable za procenu brzine relativno malo odstupaju od normalne distribucije, odnosno da su blago rasplinute. Najniža vrednost koeficijenta zaobljenosti (Kurt) iznosi ,61 za sprint na $10 \mathrm{~m}$, dok je najviši 2,10 za sprint na $30 \mathrm{~m}$.

Rezultati srednjih vrednosti testova za procenu specifičnih motoričkih sposobnosti, iznose za sklekove za 2 min $65,86 \pm 11,85$, dizanje trupa za 2 min 75,22 $\pm 11,76$, trčanje na 3200 metara iznose 14,53 $\pm 1,31$ min i penjanje uz konopac $7 \mathrm{~m}$ iznosi 9,96 $\pm 2,17 \mathrm{~s}$. Vrednosti skjunisa (Skew) ukazuju da nema izražene asimetrije. Rezultati imaju blagu pozitivnu asimetričnost (epikurtičnost), što ukazuje da postoji više dobrih rezultata, ali se nalaze u granicama dozvoljenih odstupanja. Izmerene vrednosti koeficijenta zakrivljenosti (Skew) kreću se u rasponu od ,13 za dizanje trupa za 2 min do ,89 za penjanje uz konopac $7 \mathrm{~m}$. Vrednosti kurtosisa (Kurt) ukazuju da varijable za procenu motoričkih sposobnosti relativno malo odstupaju od normalne distribucije, odnosno da su blago rasplinuti i kreću se u rasponu od -,03 kod testa dizanje trupa za 2 min do 1,97 kod testa penjanje uz konopac $7 \mathrm{~m}$.

Tabela 1. Osnovni parametri deskriptivne statistike $(n=74)$

\begin{tabular}{lccccccc}
\hline & Mean & SD & Min & Max & Range & Skew & Kurt \\
\hline Sprint $10 \mathrm{~m}[\mathrm{~s}]$ & 2,01 &, 13 & 1,71 & 2,39 &, 68 &, 42 &, 61 \\
\hline Sprint $20 \mathrm{~m}[\mathrm{~s}]$ & 3,43 &, 20 & 3,09 & 4,13 & 1,04 &, 93 & 1,72 \\
\hline Sprint $10 \mathrm{~m}[\mathrm{~s}]$ & 4,78 &, 28 & 4,31 & 5,78 & 1,47 & 1,12 & 2,10 \\
\hline Sklekovi za 2 min [broj] & 65,86 & 11,85 & 42,00 & 106,00 & 64,00 &, 70 & 1,79 \\
\hline Dizanje trupa za 2 min [broj] & 75,22 & 11,76 & 48,00 & 109,00 & 61,00 &, 13 &,- 03 \\
\hline Trčanje na 3200 m [min] & 14,53 & 1,31 & 12,10 & 18,40 & 6,30 &, 50 &, 43 \\
\hline Penjanje uz konopac 7m [s] & 9,96 & 2,17 & 5,30 & 18,00 & 12,70 &, 89 & 1,97 \\
\hline
\end{tabular}

Legenda: Mean - aritmetička sredina; SD - standardna devijacija; Min - minimalna vrednost; Max - maksimalna vrednost; Range - raspon; Skew - koeficijent zakrivljenosti; Kurt - koeficijent zaobljenosti

Utvrđene interkorelacije parametara za procenu brzine kreću se od .90 do .98 , dok je međusobna povezanost parametara za procenu specifičnih motoričkih sposobnosti iznosila od .34 do .80 . Potrebno je napomenuti da su kod interkorelacija parametara za procenu parametara specifičnih motoričkih sposobnosti utvrđene i pozitivne i negativne vrednosti (ove vrednosti nisu tabelarno prikazane). 
Na osnovu rezultata prikazanih u Tabeli 2, gde su prikazane kroskorelacije parametara za procenu brzine i specifičnih motoričkih sposobnosti, može se konstatovati slaba negativna povezanost između varijabli sprinta na 10 m i sklekova za 2 min (-.46), kao i između sprinta na $10 \mathrm{~m}$ i dizanja trupa za 2 min (-.49).

Tabela 2. Kroskorelacije parametara za procenu brzine i specifičnih motoričkih sposobnosti

\begin{tabular}{lcccc}
\hline & $\begin{array}{c}\text { Sklekovi za } \\
2 \mathrm{~min}\end{array}$ & $\begin{array}{c}\text { Dizanje trupa } \\
\text { za } 2 \mathrm{~min}\end{array}$ & $\begin{array}{c}\text { Trčanje na } \\
3200 \mathrm{~m}\end{array}$ & $\begin{array}{c}\text { Penjanje } \\
\text { uz konopac } 7 \mathrm{~m}\end{array}$ \\
\hline Sprint $10 \mathrm{~m}$ & -.46 & -.49 & .21 & .43 \\
\hline Sprint $20 \mathrm{~m}$ & -.50 & -.53 & .21 & .52 \\
\hline Sprint $10 \mathrm{~m}$ & -.50 & -.53 & .22 & .54 \\
\hline
\end{tabular}

Slaba pozitivna povezanost postoji između sprinta na $10 \mathrm{~m}$ i trčanja na $3200 \mathrm{~m}(.21)$, kao i između sprinta na $10 \mathrm{~m}$ i penjanja uz konopac $7 \mathrm{~m}$ (.43). Posmatrajući korelacije varijable sprint na $20 \mathrm{~m}$ sa specifičnim motoričkim sposobnostima, utvrđeno je da postoje značajne relacije sa sklekovima za 2 min (-.50) i dizanju trupa za 2 min (-.53), kao i slabe pozitivne relacije sa trčanjem na $3200 \mathrm{~m}(.21)$ i penjanjem uz konopac $7 \mathrm{~m}(.52)$. I kod relacija sprinta na $30 \mathrm{~m}$ mogu se konstatovati značajne negativne korelaciji sa sklekovima za 2 min (-.50) i dizanjem trupa za 2 min (-.53), dok postoje slabe pozitivne korelaciji sa trčanjem na $3200 \mathrm{~m}(.22)$ i značajne pozitivne korelacije sa penjanjem uz konopac $7 \mathrm{~m}(.54)$.

Za utvrđivanje povezanosti između parametara za procenu brzine i parametara za procenu specifičnih motoričkih sposobnosti primenjena je kanonička korelaciona analiza. Rezultati prikazani u Tabeli 3 pokazuju da su prostori brzine i specifičnih motoričkih sposobnosti međusobno povezani sa jednim parom statistički značajnih kanoničkih faktora na nivou značajnosti od $.01(\mathrm{p}=.000)$. Izolovani par kanoničkih faktora objašnjava 43\% (Can R-sqr.43) zajedničkog varijabiliteta.

Tabela 3. Kanoničke korelacije brzine i specifičnih motoričkih parametara

\begin{tabular}{|c|c|c|c|c|c|}
\hline & Can R & Can R-sqr. & Chi-sqr. & $\mathrm{df}$ & $\mathrm{p}$ \\
\hline 0 & .66 & .43 & 42,50 & 12 & $.000 * *$ \\
\hline 1 & .17 & .03 & 3,22 & 6 & .780 \\
\hline 2 & .13 & .02 & 1,09 & 2 & .579 \\
\hline \multicolumn{6}{|c|}{$\begin{array}{l}\text { Legenda: Can } \mathrm{R} \text { - koeficijent kanoničke korelacije; Can R-sqr. - procenat zajedničke varijanse; } \\
\text { Chi-sqr. - značajnost veza istraživanog prostora; } d f-\text { stepen slobode; } \mathrm{p} \text { - statistička značajnost; } \\
\text { nivo značajnosti: }{ }^{* *} \mathrm{p}<.01 \text {. }\end{array}$} \\
\hline
\end{tabular}

Analizom rezultata faktorske strukture brzine (Tabela 4), može se konstatovati da sprint na $30 \mathrm{~m}(.98)$ i sprint na $20 \mathrm{~m}$ (.96) imaju najveće pozitivne projekcije na prvi kanonički faktor, pa samim tim i najviše uslovljavaju rezultate u svim testovima specifičnih motoričkih sposobnosti, pa se ovaj faktor može definisati kao faktor brzine. Nešto manji, ali značajan uticaj na manifestacije specifičnih motoričkih sposobnosti ima sprint na $10 \mathrm{~m}(.83)$. Posmatrajući rezultate faktorske strukture specifičnih motoričkih sposobnosti uočava se da najveće projekcije na prvi kanonički faktor ima penjanje uz konopac $7 \mathrm{~m}(.85)$, zatim dizanje trupa za $2 \mathrm{~min}(-.80)$ i sklekovi za $2 \mathrm{~min}$ (-.74), pa se ovaj faktor može nazvati faktorom snage.

Tabela 4. Faktorska struktura izolovanih kanoničkih faktora brzine i specifičnih motoričkih sposobnosti

\begin{tabular}{lc|lc}
\hline & Root 1 & \multicolumn{2}{c}{ Root 1} \\
\hline Sprint $10 \mathrm{~m}$ & .83 & Sklekovi za 2 min & -.74 \\
\hline Sprint $20 \mathrm{~m}$ & .96 & Dizanje trupa za 2 min & -.80 \\
\hline Sprint $10 \mathrm{~m}$ & .98 & Trčanje na 3200 $\mathrm{m}$ & .31 \\
\hline & & Penjanje uz konopac 7 m & .85 \\
\hline
\end{tabular}




\section{DISKUSIJA}

Upoređujući deskriptivne parametre specifičnih motoričkih sposobnosti testiranog uzorka sa preporučenim standardima za fizičku proveru (Uputstvo za fizičku obuku Vojske Srbije, 2011), može se konstatovati da je nivo specifičnih motoričkih sposobnosti ispitanika vrlo visok. Visok nivo motoričkih sposobnosti utiče na uspešnost obavljanja velikog broja zadataka (Hauschild et al., 2017), a samim tim i na povećanje borbene gotovosti. Srednja vrednost u disciplini sklekovi viša je od preporučenog standarda (48), što ukazuje da je kod testiranog uzorka snaga grudnih mišića i mišića ruku na visokom nivou, na šta ukazuju i rezultati drugih autora (Vaara et al., 2012). Repetitivna snaga trupa (dizanje trupa sa tla) je znatno viša od standarda (60), ali je utvrđen relativno veliki raspon što ukazuje da postoji velika razlika u repetitivnoj snazi kod pojedinih ispitanika. Rezultati studija stranih armija (Pihlainen et al., 2018) repetitivnu snagu trupa navode kao jedan od faktora koja pokazuju najveću korelaciju sa rezultatima na vojnim poligonima spretnosti, pa su ovako dobijene vrednosti u ovom istraživanju u skladu sa očekivanjem. U disciplini penjanje uz konopac $7 \mathrm{~m}$ dobijene srednje vrednosti niže su za 4.04 sekunde od propisanog standarda (Uputstvo za fizičku obuku Vojske Srbije, 2011), što su u ovom slučaju bolji rezultati. Na osnovu dobijenih rezultata može se konstatovati da ispitanici uključeni u istraživanje imaju zavidan nivo tehnike penjanja kao i repetitivne snage. I vrednosti aerobnih sposobnosti procenjenih testom trčanja na $3200 \mathrm{~m}$, nalaze se na visokom nivou. Upoređujući srednju vrednost sa standardom fizičke provere, može se primetiti da je vreme trčanja za 1.07 minuta manje od preporučenih vrednosti, što su u ovom slučaju bolji rezultati. Druge studije ukazuju da su aerobne sposobnosti bitan faktor za uspešno obavljanje dodeljenih borbenih zadataka (Hauschild et al., 2017) i da one moraju biti na visokom nivou, što je u skladu sa dobijenim rezultatima naše studije.

Na Tabeli 2 prikazane su kroskorelacije parametara za procenu brzine i specifičnih motoričkih sposobnosti. Analizirajući rezultate merenja, može se zaključiti da postoji povezanost između parametara brzine i repetitivne snage, kao i da je brzina u nešto slabijoj korelaciji sa aerobnim sposobnostima. Između testova za procenu brzine i discipline sklekova na tlu mogu se primetiti pozitivne korelacije koje ukazujuju da povećanje brzinskih sposobnosti dovodi do značajnijeg povećanja repetitivne snage grudnih mišića i mišića ruku. Slične relacije uočavaju se i između testova za procenu brzine i dizanja trupa sa tla, što navodi na zaključak da sprinterske sposobnosti u značajnoj meri pozitivno utiču na repetitivnu snagu. Rezultati ovog istraživanja poklapaju se sa rezultatima prethodno realizovanih studija (Pavlović i Radinović, 2010). Određena povezanost uočava se između testova za procenu brzinskih sposobnosti i rezultata na trčanju $3200 \mathrm{~m}$ (.21), ali su slabije nego što je to slučaj sa repetitivnom snagom. Dobijeni rezultati ukazuju da sa poboljšanjem sprinterskih sposobnosti, odnosno brzine, ne dolazi do značajnijeg povećanja aerobne izdržljivosti. Slične rezultate u svojim istraživanjima dobili su i drugi autori koji ukazuju na visoke korelacije između sprinta, jačine i snage (Sleivert \& Taingahue, 2004; Cronin et al., 2008; Cormie et al., 2010), ali slabu povezanost sa aerobnim sposobnostima. Testovi za procenu brzine na $10 \mathrm{~m}, 20 \mathrm{~m}$ i $30 \mathrm{~m}$ odvijaju se u anaerobnim uslovima, dok disciplina trčanje na $3200 \mathrm{~m}$ spada u testove za proveru aerobne izdržljivosti, pa se time može objasniti ovako mala korelacija između ovih testova. Značajne pozitivne korelacije postoje i između testova za procenu brzine i penjanja uz konopac $7 \mathrm{~m}$. Značajne korelacije između brzine i rezultata penjanja uz konopac mogu se objasniti i time što se prilikom tehnike penjanja uz konopac koriste i noge, pa samim tim se može zaključiti da će se sa povećanjem sprinterskih sposobnosti poboljšati i rezultat u penjanju uz konopac.

Prikazane relacije između parametara za procenu brzine i parametara za procenu specifičnih motoričkih sposobnosti ukazuju da su prostori brzine i specifičnih motoričkih sposobnosti međusobno povezani sa jednim parom statistički značajnih kanoničkih faktora na nivou značajnosti od .05. Dobijeni rezultati ukazuju da promena pojedinog prostora utiče na promene drugog. Do sličnih rezultata došli su i drugi autori. U istraživanjima Young et al. (1995), Plisk (2008), Parchmann \& McBride (2011), Triplett et al. (2012) i Maleš i sar. (2004) dokazane su veze između brzine i parametara pojedinih motoričkih sposobnosti.

\section{ZAKLJUČAK}

Istraživanje je sprovedeno sa ciljem da se utvrde relacije brzine sa specifičnim motoričkih sposobnostima pripadnika specijalnih jedinica Vojske Republike Srbije. Na osnovu rezultata kros korelacija i kanoničke korelacione analize između brzine i specifičnih motoričkih sposobnosti, utvrđeno je da postoji statistički značajna povezanost brzine i specifičnih motoričkih sposobnosti kod pripadnika specijalnih jedinica. Rezultati dobijeni ovim istraživanjem 
pokazali su da brzina statistički značajno utiče na pojedine specifične motoričke sposobnosti. Dobijeni rezultati su u skladu sa drugim studijama. Buduća istraživanja potrebno je usmeriti na utvrđivanje povezanosti između drugih antropoloških parametara pripadnika specijalne brigade i specifičnih motoričkih sposobnosti kako bi se na osnovu njih dobili podaci o mogućim relacijama i predložili programi za poboljšanje njihovih performansi.

\section{LITERATURA}

1. Bubnjević, P., Vukićević, V., Lukić, N. i Miličković, V. (2020). Povezanost rezultata testova eksplozivne snage i brzine kod mladih fudbalera. Sport - Nauka i praksa, 10(1), 29-38.

2. Centers for Disease Control and Prevention. (2013). National Health and Nutrition Examination Survey (NHANES) Anthropometry Procedures Manual. US Department of Health and Human Services, Centers for Disease Control and Prevention.

3. Cormie, P., McGuigan, M.R. \& Newton, R.U. (2010). Adaptations in athletic performance after ballistic power versus strength training. Medicine \& Science in Sports \& Exercise, 42(8), 1582-1598.

4. Crawford, K., Fleishmati, K., Abt, P.J., Sell, C.T., Lovalekar, M., Nagai, T., Deluzio, J., Rowe, S.R., McGrail, A.M. \& Lephart, M.S. (2011). Less Body Fat Improves Physical and Physiological Performance in Army Soldiers. Military Medicine, 176(1), 35-43.

5. Cronin, J.B. \& Templeton, R.L. (2008). Timing light height affects sprint times. The Journal of Strength \& Conditioning Research, 22(1), 318-320.

6. Dhahbi, W., Chaouachi, A., Padulo, J., Behm, D.G. \& Chamari, K. (2015). Five-meter rope-climbing: a commando-specific power test of the upper limbs. International Journal of Sports Physiology and Performance, 10(4), 509-515.

7. Družeta, K. (2008). Dijagnostika kondicijske pripremljenosti djelatnih vojnih osoba Oružanih snaga Republike Hrvatske. (Diplomski rad). Zagreb: Kineziološki fakultet Sveučilišta u Zagrebu.

8. Duthie, G.M., Pyne, D.B., Ross, A.A., Livingstone, S.G. \& Hooper, S.L. (2006). The reliability of ten-meter sprint time using different starting techniques. The Journal of Strength \& Conditioning Research, 20(2), 246251.

9. Glavač, B.T. (2015). Motoričke sposobnosti, morfološki status i životne navike kod pripadnika Vojske Srbije (Doktorska disertacija). Beograd: Univerzitet u Beogradu, Fakultet sporta i fizičkog vaspitanja.

10. Grier, T., Canham-Chervak, M., Sharp, M. \& Jones, B. H. (2015). Does body mass index misclassify physically active young men. Preventive Medicine Reports, 2, 483-487.

11. Hauschild, V.D., DeGroot, D.W., Hall, S.M., Grier, T.L., Deaver, K.D., Hauret, K.G. \& Jones, B.H. (2017). Fitness tests and occupational tasks of military interest: a systematic review of correlations. Occupational and Environmental Medicine, 74(2), 144-153.

12. Heinrich, M.K., Jitnarin, N., Suminski, R.R., Berkel, L.V., Hunter, M.C., Alvarez, L., Antionette, R., Brundige, R.A., Peterson, L.A., John, P., Foreyt, P. J., Haddock, K. \& Poston, S.C.W. (2008). Obesity classification in military personnel: A comparison of body fat, waist circumference, and body mass index measurements. Military Medicine, 173(1), 67-73.

13. Jukić, I., Vučetić, V., Aračić, M., Bok, D., Dizdar, D., Sporiš, G. i Križanić, A. (2008). Dijagnostika kondicijske pripremljenosti vojnika. Zagreb: Kineziološki fakultet Sveučilišta u Zagrebu i Institut za istraživanje i razvoj obrambenih sustava.

14. Karalejić, M. i Jakovljević, S. (2008). Teorija i metodika košarke. Beograd: Fakultet sporta i fizičkog vaspitanja.

15. Kasum, G. (2001). Influence of morphologic and motoric features of students of the Faculty of physical culture in Belgrade on the efficiency of wrestling curriculum. Fizička kultura, 55(1-4), 42-48.

16. Mala, J., Szivak, T.K., Flanagan, S.D., Comstock, B.A., Laferrier, J.Z., Maresh, C.M. \& Kraemer, W.J. (2015). The role of strength and power during performance of high intensity military tasks under heavy load carriage. US Army Medical Department Journal, 3-12.

17. Maleš, B., Dragičević, S. i Erceg, M. (2004). Utjecaj motoričkih sposobnosti na realizaciju sprinta kod ročnih vojnika. Školski vjesnik, 1-2; 111-117.

18. Marić, L. (2010). Razvoj motoričkih sposobnosti i njihove relacije sa motoričkom efikasnošću studenata Vojne akademije. Doktorska disertacija, Novi Sad: ACIMSI. 
19. Mattila, V.M., Tallroth, K.A.J., Marttinen, M. \& Pihlajamäki, H. (2007). Physical fitness and performance. Body composition by DEXA and its association with physical fitness in 140 conscripts. Medicine and Science in Sports and Exercise, 39(12), 2242-2247.

20. Mullie, P., Vansant, G. Hulens, M., Clarys, P. \& Degrave, E. (2008). Evaluation of body fat estimated from body mass index and impedance in belgian male military candidates: Comparing two methods for estimating body composition. Military Medicine, 173(3), 266-70.

21. Nedeljković, A. (2007). Uticaj telesnih dimenzija na ispoljavanje maksimalne snage mišića (Doktorska disertacija). Beograd: Fakultet sporta i fizičkog vaspitanja.

22. Nogueira, E.C., Porto, L.G.G., Nogueira, R.M., Martins, W.R., Fonseca, R.M., Lunardi, C.C. \& de Oliveira, R.J. (2016). Body composition is strongly associated with cardiorespiratory fitness in a large Brazilian military firefighter cohort: the Brazilian firefighters study. The Journal of Strength \& Conditioning Research, 30(1), 33-38.

23. Parchmann, C.J. \& McBride, J.M. (2011). Relationship between functional movement screen and athletic performance. The Journal of Strength \& Conditioning Research, 25(12), 3378-3384.

24. Pavlović, R. i Radinović, Z. (2010). Motoričke sposobnosti kao faktori uspjeha u atletici. Sport i zdravlje, 5(2), 96-103.

25. Pierce, J.R., De Groot, D.W., Grier, T.L., Hauret, K.G., Nindl, B.C., East, W.B... \& Jones, B.H. (2017). Body mass index predicts selected physical fitness attributes but is not associated with performance on military relevant tasks in US Army Soldiers. Journal of Science and Medicine in Sport, 20, S79-S84.

26. Pihlainen, K., Santtila, M., Häkkinen, K. \& Kyröläinen, H. (2018). Associations of physical fitness and body composition characteristics with simulated military task performance. The Journal of Strength \& Conditioning Research, 32(4), 1089-1098.

27. Plisk S. (2008). Speed, agility, and speedendurance development. In: Baechle T.R. and Earle R.W. eds., Essentials of Strength Training and Conditioning - NSCA (3rd ed) (pp. 458-485). Champaign, IL: Human Kinetics.

28. Popović, B. (2010). The influence of morphological and motor characteristics of students of the Faculty of Physical Education in Belgrade on the efficiency of mastering judo curriculum. Fizička kultura, 64(1), 62-71.

29. Sleivert, G. \& Taingahue, M. (2004). The relationship between maximal jump-squat power and sprint acceleration in athletes. European Journal of applled Physiology, 91(1), 46-52.

30. Šimenko, J., Čoh, M., Škof, B., Zorec, B. \& Milić, R. (2014). Comparison of Some Morphological and Physiological Characteristics of Slovenian Police Special Unit and American Special Forces SWAT. Journal of Criminal Justice and Security, (3), 312-320.

31. Triplett, N.T., Erickson, T.M. \& McBride, J.M. (2012). Power associations with running speed. Strength \& Conditioning Journal, 34(6), 29-33.

32. Uputstvo za fizičku obuku u Vojsci Srbije (2011). Uprava za obuku i doktrinu. Beograd: Generalštab Vojske Srbije.

33. Vaara, J.P., Kyröläinen, H., Niemi, J., Ohrankämmen, O., Häkkinen, A., Kocay, S. \& Häkkinen, K. (2012). Associations of maximal strength and muscular endurance test scores with cardiorespiratory fitness and body composition. The Journal of Strength \& Conditioning Research, 26(8), 2078-2086.

34. Veličković, S., Petković, D. \& Petković, E. (2013). The effects of programmed physical preparation on the transformation of motor skills of young soldiers of various specialties. Military Operations Research, 18(2), 49-59.

35. Young, W., Mc Lean, B. \& Ardagna, J. (1995). Relationship between strength qualities and sprinting performance. Journal of Sports Medicine and Physical Fitness, 35(1), 13-19. 
SPORT - Science \& Practice, Vol. 11, №1, 2021, pp. 1-8.

Original scientific paper

\title{
RELATIONS OF SPEED AND SPECIFIC MOTOR ABILITIES OF SPECIAL UNIT MEMBERS ${ }^{1}$
}

\author{
UDC: 796.012.1-057.36(497.11) \\ https://doi.org/10.18485/snip.2021.11.1.en.1
}

Mihajlo Golubović ${ }^{2}$

Faculty of Sport and Physical Education, University of Niš, Serbia

Saša Veličković

Faculty of Sport and Physical Education, University of Niš, Serbia

Anđela Đošić

Faculty of Sport and Physical Education, University of Niš, Serbia

Saša Pantelić ${ }^{3}$

Faculty of Sport and Physical Education, University of Niš, Serbia

\begin{abstract}
The operational abilities of the members of the army are defined by the factors of morphology, function, levels of motor skills, health, etc. In special brigades, a high level of motor skills is required for the successful realization of assigned tasks. The most important motor skills of the Special Brigades members are endurance, strength, coordination, agility and speed, as well as balance, precision and flexibility. These parameters must be interrelated in order to expect maximum performance. The aim of the research was to determine whether there is a connection between speed and specific motor abilities of the special brigade members in the Serbian Armed Forces (SAF). The sample consisted of 74 respondents, members of the 63rd Parachute Brigade from Nis. To determine the speed, the following tests were used: sprint at $10 \mathrm{~m}, 20 \mathrm{~m}$ and $30 \mathrm{~m}$. Specific motor skills were assessed by the following tests: push-ups on the ground for 2 minutes, lifting the torso off the ground for 2 minutes, $3200 \mathrm{~m}$ running, $7 \mathrm{~m}$ rope climbing. The canonical correlation analysis was applied to determine the relationship between speed and the parameters of specific motor abilities. Data processing was conducted using the statistical package Statistica 8.0. The significance level was .05 . The results indicated the interrelation of speed and specific motor abilities with one pair of statistically significant canonical factors at the significance level of $.01(\mathrm{p}=.000)$. The isolated pair of canonical factors was explained with $43 \%$ of the common variability.
\end{abstract}

Key words: motor skills, special brigade, speed, relations

\section{INTRODUCTION}

Earlier studies show that in addition to functional and anthropometric characteristics, the level of certain motor abilities is of great importance for achieving success in certain sports, whether it is adults' (Kasum, 2001; Karalejić \& Jakovljević, 2008; Popović, 2010) or children's growth (Bubnjević et al., 2020). Also, the success of executing certain physical activities directly determines the level of individual motor abilities of an individual (Nedeljković, 2007).

Paper received: 1 March 2021, edited: 23 March 2021, accepted for publication: 23 March 2021

2 Mihajlo Golubović is a PhD student at the Faculty of Sport and Physical Education, University of Niš.

3凶panta@fsfv.ni.ac.rs 
Their share depends on a large number of factors, but also on the nature and complexity of the movement structure of a certain sports branch or discipline. An example of a very pronounced role of certain motor abilities in achieving top results is reflected, for example, in the execution of athletic movement structures, such as running, jumping or throwing events, where certain relations are manifested through a sports result (Pavlović \& Radinović, 2010). Determining the level of motor abilities and anthropological characteristics and their influence on certain indicators of physical abilities is a current problem not only in sports practice, but also in the army, which requires a high level of physical abilities. A high level of physical ability greatly affects the success in performing many tasks (Hauschild et al., 2017), and thus increases the combat readiness of the unit.

The level of operational abilities of members of the army is defined by a number of factors related to physiological and morphological characteristics, functional abilities, level of motor skills, health, etc. (Marić, 2010; Šimenko et al., 2004). In the army, and especially in special units, a high level of motor skills is required for the successful accomplishment of assigned tasks. Members of special brigades often perform training and various tasks in difficult meteorological conditions and under load (protective mask, combat equipment, protective clothing, etc.), where a large number of motor skills are pronounced. The main motor factors that are responsible for the successful execution of combat tasks by special brigades' members are cardiorespiratory endurance and strength (Družeta, 2008; Mattila et al., 2007; Mala et al., 2015). Some authors claim that mainly muscle strength and power are considered to be the most important physical attributes for executing military tasks, while aerobic abilities are given less importance (Pierce et al., 2017). Leg strength is particularly important during long marches, when leaving and returning from a training ground or a shooting range, when crossing certain obstacles, etc. (Mattila et al., 2007; Družeta, 2008; Mala et al., 2015). The importance of explosive power can be seen in mastering various training grounds, fast boarding and disembarking from combat vehicles, breaching into facilities, etc. (Pihlainen et al., 2018). In addition to strength, aerobic endurance is an important factor for the execution of training and combat tasks. Members of special brigades, as part of regular training, go on marches under load, in difficult meteorological conditions, at low and high temperatures, where the total length of the march is up to $50 \mathrm{~km}$, and the load, i.e. the weight of combat equipment, ranges from 20 to $40 \mathrm{~kg}$.

Other factors that boost the combat readiness of a unit and the level of operational capabilities include coordination, especially whole body coordination, the speed of executing complex motor tasks, agility and speed (Družeta, 2008). Also, balance, precision and flexibility are among the motor skills that are important in the army, and especially in special units (Družeta, 2008).

In order to determine the state of motor abilities of professional military personnel, and for the purpose of uniform performance of checks and assessments, a battery of tests recommended for this population group is used (Instruction for Physical Training of the Serbian Army, 2011).

The results of the research that dealt with the relations of motor abilities in members of the army were mainly based on determining the relations of body composition and other motor abilities (Glavač, 2015; Heinrich et al., 2008; Mullie et al., 2008; Crawford et al., 2011). Based on the results of the previous research (Grier et al., 2015; Nogueira et al., 2016), it was determined that BMI and body fat percentage are strongly negatively correlated with aerobic capacity and the results on military fitness tests.

Some studies have established the influence of motor skills on the realization of speed in members of the army (Maleš et al., 2004). The authors conclude that a large number of motor skills play a role in success in running, and that the integration of motor skills is omnipresent.

The aim of this study was to determine whether there is a connection between speed and specific motor skills in the members of special units in the SAF.

\section{METHOD}

\section{The sample of respondents}

The population that made up the sample of respondents was composed of the members of the 63rd Parachute Brigade in Nis. The total sample included 74 male subjects, whose average age was $33.3 \pm 5.7$. The average body height of the subjects was $178.65 \pm 6.64 \mathrm{~cm}$, body weight $84.08 \pm 9.59 \mathrm{~kg}$, while their BMI was $26.33 \pm 2.41 \mathrm{~kg} / \mathrm{m} 2$. The subjects that were included in this sample belong to the group of physically active population. As part of physical training, they exercise for 90 minutes every day. At the time of the survey, all respondents had good health status. 


\section{The sample of measuring instruments}

In accordance with the aim of the research, speed assessment tests and tests for the assessment of specific motor abilities were applied.

Speed assessment measuring instruments

The following tests were used to assess running speed (Veličković et al., 2013; Jukić et al., 2008):

- $10 \mathrm{~m}$ sprint,

- $20 \mathrm{~m}$ sprint and

- $30 \mathrm{~m}$ sprint.

Measuring instruments for the assessment of specific motor abilities

For the assessment of specific motor abilities, the tests used when checking the motor abilities in the Serbian Army were applied (Instruction for Physical Training of the Serbian Army, 2011):

- push-ups on the ground in 2 minutes,

- lifting the torso off the ground in 2 minutes,

- $3200 \mathrm{~m}$ running and

- $7 \mathrm{~m}$ rope climbing.

\section{Description of the measurement procedure}

For the sake of the research, the necessary optimal conditions were created during the measurement. The measurement of anthropometric characteristics was developed according to the method of the Centres for Disease Control and Prevention (2017), and BMI was calculated on the basis of a template proposed by the World Health Organization (WHO, 1997).

The WITTY SEM electronic timekeeping system with photocells was used to assess the speed. From the high start, the examinees were instructed to cross the distance of $30 \mathrm{~m}$ as fast as possible, and the photo-cells placed on the starting line, at $10 \mathrm{~m}, 20 \mathrm{~m}$ and $30 \mathrm{~m}$, recorded the time. The applied tests have satisfactory metric characteristics, and along with the same equipment, they have been used in other studies (Duthie et al., 2006; Jukić et al., 2008).

Specific motor skills that were tested were based on the Instruction for Physical Training in the SAF and the Standards for Assessing the Physical Ability of Military Personnel in the SAF (Instruction for Physical Training in the Serbian Army, 2011). Using a battery of tests to check physical abilities, the following parameters were assessed: repetitive endurance in the strength of the arms, shoulder girdle, chest muscles and torso, aerobic endurance and the endurance of leg muscles, as well as general physical ability. The applied tests have satisfactory metric characteristics (Jukić et al., 2008; Dhahbi et al., 2015).

Push-ups on the ground for 2 minutes,

The respondent starts performing push-ups, from the initial push-up position. An attempt to lower the whole body until the upper arms are parallel to the ground, and then return to the starting position is considered a correct push-up. With each repetition, the body must remain in a straight line. After two minutes, the test is interrupted, resulting in the number of correct repetitions over two minutes. This test has satisfactory metric characteristics, which was confirmed by a group of authors (Jukić et al., 2008).

\section{Lifting the torso off the ground for 2 minutes}

The subject performs sit-ups from the initial position: lying on the back with the knees bent at an angle of $90^{\circ}$ and the feet spread at the width of the hips, which were supported by another subject, with the arms crossed and pressed to the chest. During the test, the hands are on the chest all the time. After two minutes have elapsed, the number of correct repetitions over two minutes is entered as the result.

\section{0 m running}

Respondents start running, and immediately time measuring starts. After running the distance of $3200 \mathrm{~m}$, as a result of the test, the time during which the respondent ran the indicated section is entered. The time was entered with an accuracy of one second (minute, second).

$7 m$ rope climbing

From the initial position in which the examinee stood next to the rope and held on to the rope with one hand, they start climbing up the rope at the command of the examiner. The climbing technique was chosen by the 
respondent himself. The test ended when the subject touched a marker with their hand that indicated a height of $7 \mathrm{~m}$, and the time was entered with an accuracy of $0.10 \mathrm{~s}$ (seconds, tenths of a second).

\section{Statistical data processing}

The statistical data processing package Statistica 8.0 for Windows (StatSoft, Inc., Tulsa, OK) was used for processing and analysis of raw data.

The basic parameters of descriptive statistics and distribution were calculated (arithmetic mean, standard deviation, minimum and maximum value, range, curvature coefficient - skewness, roundness coefficient - kurtosis). Canonical correlation analysis was used to determine the relationship between speed and the parameters of specific motor abilities. The canonical correlation coefficient, the percentage of common variance, the significance of the connections of the investigated space, the degree of freedom and the statistical significance of the canonical correlation analysis were calculated. The significance level was .05.

\section{RESULTS}

Table 1 shows the parameters of descriptive statistics and distribution of applied variables for estimating speed and specific motor abilities.

The mean value of the $10 \mathrm{~m}$ sprint is $2.01 \pm 0.13 \mathrm{~s}$, the $20 \mathrm{~m}$ sprint is $3.43 \pm 0.20 \mathrm{~s}$, while the mean value of the $30 \mathrm{~m}$ sprint is $4.78 \pm 0.28 \mathrm{~s}$. Skewness values indicate that there is no expressed asymmetry. The results have a slightly positive asymmetry (epicurticity), which indicates that there are several good results, but it can be stated that they are within the permissible deviations. The lowest value of the curvature coefficient (Skew) is .42 for the $10 \mathrm{~m}$ sprint, while the highest is 1.12 for the $30 \mathrm{~m}$ sprint. The values of kurtosis (Kurt) indicate that the variables for estimating the velocity deviate relatively little from the normal distribution, i.e. that they are slightly incompact. The lowest value of the rounding coefficient (Kurtosis) is .61 for the $10 \mathrm{~m}$ sprint, while the highest is 2.10 for the $30 \mathrm{~m}$ sprint.

The results of the mean values of tests for the assessment of specific motor abilities are the following: for push-ups for $2 \min 65.86 \pm 11.85$, for lifting the torso for $2 \min 75.22 \pm 11.76$, for $3200 \mathrm{~m}$ running $14.53 \pm 1.31 \mathrm{~min}$ and for $7 \mathrm{~m}$ rope climbing $9.96 \pm 2.17 \mathrm{~s}$. Skewness values indicate that there is no pronounced asymmetry. The results have a slightly positive asymmetry (epicurticity), which indicates that there are several good results, but they are within the allowed tolerance. The measured values of the coefficient of curvature (Skew) range from .13 for lifting the torso for $2 \mathrm{~min}$ to .89 for $7 \mathrm{~m}$ rope climbing. The values of kurtosis (Kurt) indicate that the variables for the assessment of motor skills deviate relatively little from the normal distribution, i.e. that they are slightly incompact and range from --.03 in the test torso lift for $2 \mathrm{~min}$ to 1.97 in the test of $7 \mathrm{~m}$ rope climbing.

Table 1. Basic parameters of descriptive statistics $(n=74)$

\begin{tabular}{lccccccc}
\hline & Mean & SD & Min & Max & Range & Skew & Kurt \\
\hline Sprint 10m [s] & 2,01 &, 13 & 1,71 & 2,39 &, 68 &, 42 &, 61 \\
\hline Sprint 20m [s] & 3,43 &, 20 & 3,09 & 4,13 & 1,04 &, 93 & 1,72 \\
\hline Sprint 30m [s] & 4,78 &, 28 & 4,31 & 5,78 & 1,47 & 1,12 & 2,10 \\
\hline Push-ups for 2 min [number] & 65,86 & 11,85 & 42,00 & 106,00 & 64,00 &, 70 & 1,79 \\
\hline Lifting the torso for 2 min[number] & 75,22 & 11,76 & 48,00 & 109,00 & 61,00 &, 13 &,- 03 \\
\hline 3200m running[min] & 14,53 & 1,31 & 12,10 & 18,40 & 6,30 &, 50 &, 43 \\
\hline 7m rope climbing [s] & 9,96 & 2,17 & 5,30 & 18,00 & 12,70 &, 89 & 1,97 \\
\hline
\end{tabular}

Legend: Mean - arithmetic mean; SD - standard deviation; Min - minimum value; Max - maximum value; Range - range; Skew - curvature coefficient; Kurt - coefficient of roundness

The determined interrelations of parameters for speed assessment range from .90 to .98 , while the correlation of parameters for the assessment of specific motor abilities ranged from .34 to .80 . It should be noted that in the interrelation of parameters for the assessment of parameters of specific motor abilities, both positive and negative values were determined (these values are not shown in the table). 
Based on the results shown in the Table 2, where cross-correlations of parameters for assessing speed and specific motor skills are shown, a weak negative correlation can be found between the variables of the $10 \mathrm{~m}$ sprint and push-ups for $2 \mathrm{~min}(-.46)$, as well as between the $10 \mathrm{~m}$ sprint and lifting the torso for $2 \mathrm{~min}(-.49)$.

Table 2. Cross-correlations of parameters for estimating speed and specific motor abilities

\begin{tabular}{lcccc}
\hline & $\begin{array}{c}\text { Push-ups } \\
\text { for } 2 \mathrm{~min}\end{array}$ & $\begin{array}{c}\text { Lifting the torso } \\
\text { for } 2 \mathrm{~min}\end{array}$ & 3200m running & $\begin{array}{c}7 \mathrm{~m} \text { rope } \\
\text { climbing }\end{array}$ \\
\hline Sprint $10 \mathrm{~m}$ & -.46 & -.49 & .21 & .43 \\
\hline Sprint $20 \mathrm{~m}$ & -.50 & -.53 & .21 & .52 \\
\hline Sprint $10 \mathrm{~m}$ & -.50 & -.53 & .22 & .54 \\
\hline
\end{tabular}

There is a weak positive connection between the $10 \mathrm{~m}$ sprint and the $3200 \mathrm{~m}$ run $(.21)$, as well as between the $10 \mathrm{~m}$ sprint and the $7 \mathrm{~m}$ rope climbing (.43). Observing the correlations of the variable $20 \mathrm{~m}$ sprint with specific motor abilities, it was found that there are significant relations with push-ups for $2 \mathrm{~min}(-.50)$ and torso lift for $2 \mathrm{~min}$ $(-.53)$, as well as weak positive relations with $3200 \mathrm{~m}$ running (.21) and $7 \mathrm{~m}$ rope climbing (.52). Significant negative correlations with push-ups for $2 \mathrm{~min}(-.50)$ and lifting the torso for $2 \mathrm{~min}(-.53)$ can also be found in the $30 \mathrm{~m}$ sprint, while there are weak positive correlations with $3200 \mathrm{~m}$ running $(.22)$ and significant positive correlations with the $7 \mathrm{~m}$ rope climbing (.54).

The canonical correlation analysis was applied to determine the relationship between the parameters for estimating speed and the parameters for estimating specific motor abilities. The results shown in the Table 3 show that speed and specific motor abilities are interrelated with one pair of statistically significant canonical factors at a significance level of .01 ( $\mathrm{p}=.000)$. An isolated pair of canonical factors explains $43 \%$ (Can R-sqr.43) of the common variability.

Table 3. Canonical correlations of speed and specific motor parameters

\begin{tabular}{|c|c|c|c|c|c|}
\hline & Can R & Can R-sqr. & Chi-sqr. & df & $\mathrm{p}$ \\
\hline 0 & .66 & .43 & 42,50 & 12 & $.000 * *$ \\
\hline 1 & .17 & .03 & 3,22 & 6 & .780 \\
\hline 2 & .13 & .02 & 1,09 & 2 & .579 \\
\hline \multicolumn{6}{|c|}{$\begin{array}{l}\text { Legend: Can R - canonical correlation coefficient; Can R-sqr. - percentage of common variance; } \\
\text { Chi-sqr. - significance of connections of the researched space; df - degree of freedom; p - statistical } \\
\text { significance; significance level: } * * p<.01 \text {. }\end{array}$} \\
\hline
\end{tabular}

By analyzing the results of the velocity factor structure (Table 4), it can be concluded that the $30 \mathrm{~m}$ sprint (.98) and the $20 \mathrm{~m}$ sprint (.96) have the highest positive projections on the first canonical factor, and therefore the most conditioned results in all of the tests of specific motor abilities, so this factor can be defined as the speed factor. The 10m sprint (.83) has slightly lower, but still significant influence on the manifestations of specific motor abilities. Observing the results of the factor structure of specific motor abilities, it is noticed that the highest projections on the first canonical factor are featured by $7 \mathrm{~m}$ rope climbing (.85), then lifting the torso for $2 \mathrm{~min}(-.80)$ and push-ups for $2 \mathrm{~min}(-.74)$, and this factor can be called the power factor.

Table 4. Factor structure of isolated canonical factors of speed and specific motor abilities

\begin{tabular}{lc|lc}
\hline & Root 1 & \multicolumn{2}{c}{ Root 1} \\
\hline Sprint $10 \mathrm{~m}$ & .83 & Push-ups for 2 min & -.74 \\
\hline Sprint $20 \mathrm{~m}$ & .96 & Lifting the torso for 2 min & -.80 \\
\hline Sprint $10 \mathrm{~m}$ & .98 & 3200m running & .31 \\
\hline & & 7m rope climbing & .85 \\
\hline
\end{tabular}




\section{DISCUSSION}

Comparing the descriptive parameters of specific motor abilities of the tested sample with the recommended standards for physical testing (Instructions for Physical Training of the Serbian Army, 2011), it can be concluded that the level of specific motor abilities of the respondents is very high. A high level of motor skills affects the success of executing a large number of tasks (Hauschild et al., 2017), and thus increases combat readiness. The mean value in the push-up discipline is higher than the recommended standard (48), which indicates that in the tested sample the strength of the pectoral muscles and arm muscles is at a high level, as indicated by the results of other authors (Vaara et al., 2012). The repetitive strength of the torso (lifting the torso from the ground) is significantly higher than the standard (60), but a relatively large range was found, which indicates that there is a large difference in the repetitive strength of some subjects. The results of studies of foreign armies (Pihlainen et al., 2018) point to the repetitive strength of the troops as one of the factors that show the highest correlation with the results on military training grounds, so the values obtained in this study are in line with expectations. In the discipline of $7 \mathrm{~m}$ rope climbing, the obtained average values are lower by 4.04 seconds than the prescribed standard (Instructions for Physical Training of the Serbian Army, 2011), which are better results in this case. Based on the obtained results, it can be stated that the examinees included in the research have an enviable level of climbing technique as well as repetitive strength. The values of aerobic abilities estimated by the $3200 \mathrm{~m}$ running test are also at a high level. Comparing the mean value with the standard of physical tests, it can be noticed that the running time is 1.07 minutes less than the recommended values, which in this case is a better result. Other studies indicate that aerobic abilities are an important factor for the successful performance of assigned combat tasks (Hauschild et al., 2017) and that they must be at a high level, which is consistent with the results of our study.

Table 2 shows the cross-correlations of the parameters for estimating speed and specific motor abilities. Analysing the measurement results, it can be concluded that there is a correlation between the parameters of speed and repetitive power, as well as that the speed is somewhat weaker in correlation with aerobic abilities. Positive correlations can be noticed between the tests for assessing the speed and discipline of push-ups on the ground, which indicate that an increase in speed abilities leads to a significant increase in the repetitive strength of the chest and arm muscles. Similar relationships can be observed between tests for assessing the speed and lifting the torso off the ground, which leads to the conclusion that sprinting abilities have a significant positive effect on repetitive strength. The results of this research coincide with the results of previously conducted studies (Pavlović \& Radinović, 2010). Some correlation is observed between speed assessment tests and $3200 \mathrm{~m}(.21)$ running results, but they are weaker than repetitive power. The obtained results indicate that with the improvement of sprinting abilities, i.e. speed, there is no significant increase in aerobic endurance. Similar results have been obtained by other authors, who indicate high correlations between sprint, strength and power (Sleivert \& Taingahue, 2004; Cronin et al., 2008; Cormie et al., 2010), but a weak connection with aerobic capacity. Tests that assess speed at $10 \mathrm{~m}, 20 \mathrm{~m}$ and $30 \mathrm{~m}$ sprint take place in anaerobic conditions, while the 3200 running discipline is one of the tests to check aerobic endurance, so this can explain such a small correlation between these tests. Significant positive correlations also exist between the tests that assess speed and $7 \mathrm{~m}$ rope climbing. Significant correlations between speed and the results of rope climbing can be explained by the fact that legs are also used during the rope climbing technique, so it can be concluded that with the increase of sprinting abilities, the result in rope climbing will also improve.

The presented relations between the parameters for estimating speed and the parameters for estimating specific motor abilities indicate that $t$ he spaces of speed and specific motor abilities are interconnected with one pair of statistically significant canonical factors at the significance level of .05 . The obtained results indicate that the change of one space affects the changes of another. Other authors obtained similar results. The research of Young et al. (1995), Plisk (2008), Parchmann \& McBride (2011), Triplett et al. (2012) and Maleš et al. (2004) proved the existence of the connections between speed and the parameters of individual motor skills.

\section{CONCLUSION}

The research was conducted with the aim of determining the relations between speed and specific motor abilities in special units' members of the SAF. Based on the results of cross-correlations and canonical correlation analysis between speed and specific motor abilities, it was determined that there is a statistically significant 
correlation between speed and specific motor abilities in special units' members. The results obtained by this research showed that speed has a statistically significant effect on certain specific motor abilities. The obtained results are in accordance with other studies. Future research should focus on determining the relationship between other anthropological parameters of members of the special brigade and specific motor skills in order to obtain data on possible relationships and propose programs to improve their performance.

\section{REFERENCES}

1. Bubnjević, P., Vukićević, V., Lukić, N. \& Miličković, V. (2020). Povezanost rezultata testova eksplozivne snage i brzine kod mladih fudbalera. Sport - Nauka i praksa, 10(1), 29-38.

2. Centers for Disease Control and Prevention. (2013). National Health and Nutrition Examination Survey (NHANES) Anthropometry Procedures Manual. US Department of Health and Human Services, Centers for Disease Control and Prevention.

3. Cormie, P., McGuigan, M.R. \& Newton, R.U. (2010). Adaptations in athletic performance after ballistic power versus strength training. Medicine \& Science in Sports \& Exercise, 42(8), 1582-1598.

4. Crawford, K., Fleishmati, K., Abt, P.J., Sell, C.T., Lovalekar, M., Nagai, T., Deluzio, J., Rowe, S.R., McGrail, A.M. \& Lephart, M.S. (2011). Less Body Fat Improves Physical and Physiological Performance in Army Soldiers. Military Medicine, 176(1), 35-43.

5. Cronin, J.B. \& Templeton, R.L. (2008). Timing light height affects sprint times. The Journal of Strength \& Conditioning Research, 22(1), 318-320.

6. Dhahbi, W., Chaouachi, A., Padulo, J., Behm, D.G. \& Chamari, K. (2015). Five-meter rope-climbing: a commando-specific power test of the upper limbs. International Journal of Sports Physiology and Performance, 10(4), 509-515.

7. Družeta, K. (2008). Dijagnostika kondicijske pripremljenosti djelatnih vojnih osoba Oružanih snaga Republike Hrvatske. (Diplomski rad). Zagreb: Kineziološki fakultet Sveučilišta u Zagrebu.

8. Duthie, G.M., Pyne, D.B., Ross, A.A., Livingstone, S.G. \& Hooper, S.L. (2006). The reliability of ten-meter sprint time using different starting techniques. The Journal of Strength \& Conditioning Research, 20(2), 246251.

9. Glavač, B.T. (2015). Motoričke sposobnosti, morfološki status i životne navike kod pripadnika Vojske Srbije (Doktorska disertacija). Beograd: Univerzitet u Beogradu, Fakultet sporta i fizičkog vaspitanja.

10. Grier, T., Canham-Chervak, M., Sharp, M. \& Jones, B. H. (2015). Does body mass index misclassify physically active young men. Preventive Medicine Reports, 2, 483-487.

11. Hauschild, V.D., DeGroot, D.W., Hall, S.M., Grier, T.L., Deaver, K.D., Hauret, K.G. \& Jones, B.H. (2017). Fitness tests and occupational tasks of military interest: a systematic review of correlations. Occupational and Environmental Medicine, 74(2), 144-153.

12. Heinrich, M.K., Jitnarin, N., Suminski, R.R., Berkel, L.V., Hunter, M.C., Alvarez, L., Antionette, R., Brundige, R.A., Peterson, L.A., John, P., Foreyt, P. J., Haddock, K. \& Poston, S.C.W. (2008). Obesity classification in military personnel: A comparison of body fat, waist circumference, and body mass index measurements. Military Medicine, 173(1), 67-73.

13. Jukić, I., Vučetić, V., Aračić, M., Bok, D., Dizdar, D., Sporiš, G. \& Križanić, A. (2008). Dijagnostika kondicijske pripremljenosti vojnika. Zagreb: Kineziološki fakultet Sveučilišta u Zagrebu i Institut za istraživanje i razvoj obrambenih sustava.

14. Karalejić, M. \& Jakovljević, S. (2008). Teorija i metodika košarke. Beograd: Fakultet sporta i fizičkog vaspitanja.

15. Kasum, G. (2001). Influence of morphologic and motoric features of students of the Faculty of physical culture in Belgrade on the efficiency of wrestling curriculum. Fizička kultura, 55(1-4), 42-48.

16. Mala, J., Szivak, T.K., Flanagan, S.D., Comstock, B.A., Laferrier, J.Z., Maresh, C.M. \& Kraemer, W.J. (2015). The role of strength and power during performance of high intensity military tasks under heavy load carriage. US Army Medical Department Journal, 3-12.

17. Maleš, B., Dragičević, S. \& Erceg, M. (2004). Utjecaj motoričkih sposobnosti na realizaciju sprinta kod ročnih vojnika. Školski vjesnik, 1-2; 111-117. 
18. Marić, L. (2010). Razvoj motoričkih sposobnosti i njihove relacije sa motoričkom efikasnošću studenata Vojne akademije. Doktorska disertacija, Novi Sad: ACIMSI.

19. Mattila, V.M., Tallroth, K.A.J., Marttinen, M. \& Pihlajamäki, H. (2007). Physical fitness and performance. Body composition by DEXA and its association with physical fitness in 140 conscripts. Medicine and Science in Sports and Exercise, 39(12), 2242-2247.

20. Mullie, P., Vansant, G. Hulens, M., Clarys, P. \& Degrave, E. (2008). Evaluation of body fat estimated from body mass index and impedance in belgian male military candidates: Comparing two methods for estimating body composition. Military Medicine, 173(3), 266-70.

21. Nedeljković, A. (2007). Uticaj telesnih dimenzija na ispoljavanje maksimalne snage mišića (Doktorska disertacija). Beograd: Fakultet sporta i fizičkog vaspitanja.

22. Nogueira, E.C., Porto, L.G.G., Nogueira, R.M., Martins, W.R., Fonseca, R.M., Lunardi, C.C. \& de Oliveira, R.J. (2016). Body composition is strongly associated with cardiorespiratory fitness in a large Brazilian military firefighter cohort: the Brazilian firefighters study. The Journal of Strength \& Conditioning Research, 30(1), 33-38.

23. Parchmann, C.J. \& McBride, J.M. (2011). Relationship between functional movement screen and athletic performance. The Journal of Strength \& Conditioning Research, 25(12), 3378-3384.

24. Pavlović, R. \& Radinović, Z. (2010). Motoričke sposobnosti kao faktori uspjeha u atletici. Sport i zdravlje, 5(2), 96-103.

25. Pierce, J.R., De Groot, D.W., Grier, T.L., Hauret, K.G., Nindl, B.C., East, W.B... \& Jones, B.H. (2017). Body mass index predicts selected physical fitness attributes but is not associated with performance on military relevant tasks in US Army Soldiers. Journal of Science and Medicine in Sport, 20, S79-S84.

26. Pihlainen, K., Santtila, M., Häkkinen, K. \& Kyröläinen, H. (2018). Associations of physical fitness and body composition characteristics with simulated military task performance. The Journal of Strength \& Conditioning Research, 32(4), 1089-1098.

27. Plisk S. (2008). Speed, agility, and speedendurance development. In: Baechle T.R. and Earle R.W. eds., Essentials of Strength Training and Conditioning - NSCA (3rd ed) (pp. 458-485). Champaign, IL: Human Kinetics.

28. Popović, B. (2010). The influence of morphological and motor characteristics of students of the Faculty of Physical Education in Belgrade on the efficiency of mastering judo curriculum. Fizička kultura, 64(1), 62-71.

29. Sleivert, G. \& Taingahue, M. (2004). The relationship between maximal jump-squat power and sprint acceleration in athletes. European Journal of applled Physiology, 91(1), 46-52.

30. Šimenko, J., Čoh, M., Škof, B., Zorec, B. \& Milić, R. (2014). Comparison of Some Morphological and Physiological Characteristics of Slovenian Police Special Unit and American Special Forces SWAT. Journal of Criminal Justice and Security, (3), 312-320.

31. Triplett, N.T., Erickson, T.M. \& McBride, J.M. (2012). Power associations with running speed. Strength \& Conditioning Journal, 34(6), 29-33.

32. Uputstvo za fizičku obuku u Vojsci Srbije (2011). Uprava za obuku i doktrinu. Beograd: Generalštab Vojske Srbije.

33. Vaara, J.P., Kyröläinen, H., Niemi, J., Ohrankämmen, O., Häkkinen, A., Kocay, S. \& Häkkinen, K. (2012). Associations of maximal strength and muscular endurance test scores with cardiorespiratory fitness and body composition. The Journal of Strength \& Conditioning Research, 26(8), 2078-2086.

34. Veličković, S., Petković, D. \& Petković, E. (2013). The effects of programmed physical preparation on the transformation of motor skills of young soldiers of various specialties. Military Operations Research, 18(2), 49-59.

35. Young, W., Mc Lean, B. \& Ardagna, J. (1995). Relationship between strength qualities and sprinting performance. Journal of Sports Medicine and Physical Fitness, 35(1), 13-19. 